\title{
Supraventricular Bigeminy by ECG Finding
}

National Cancer Institute

\section{Source}

National Cancer Institute. Supraventricular Bigeminy by ECG Finding. NCI Thesaurus.

Code C161046.

An electrocardiographic finding of a supraventricular QRS complex followed by a premature supraventricular complex for 3 or more consecutive cycles; a regularly irregular rhythm of normal and abnormal QRS complexes in a 1-1 ratio. (CDISC) 